\title{
Dam breach reconstruction of the Blažňov pond caused by extreme hydrological event
}

\author{
MIROSLAV ŠOBR, MICHAL JENÍČEK, KLÁRA VOČADLOVÁ \\ Charles University in Prague, Faculty of Science, \\ Department of Physical Geography and Geoecology
}

\begin{abstract}
This article deals with the reconstruction of the dam breach of the Blažňov pond and consequent flood wave progress in the riverbed of the small brook. The dam breach occurred at the night from 28. 3. 2006 to 29. 3. 2006. The cause of the breach was above all increased inflow to the pond as a result of heavy rainfall together with intensive snowmelt. The earth-fill dam of the pond was in the time of breach corrupted by water rodents. The flood wave progressed through the brook valley with the length of $0.7 \mathrm{~km}$. Consequently it fulfilled the Podolí pond, which is situated below the Blažňov pond. Podolí pond was in this time empty and the flood wave was completely transformed there. Measurements of the wave course and cross-sections through valley were made by total geodetic station. An extraction of flood sediments were carried out at three locations and their textures were analyzed. The reason was a description of the sedimentation process in the reach. For the modelling of the flood extremity and flood extent the hydrodynamic model HEC-RAS was applied (Hydrologic Engineering Centre - River Analysis System).
\end{abstract}

Key words: floods - flood reconstruction - dam breach - hydrodynamic model - HEC-RAS

\section{Introduction}

The pond Blažňov is located on the left tributary of the Bílenický Brook and joins the Nezdický Brook (right tributary of Otava River in the village Žichovice) from the right side. Before breach the area of the pond Blažňov was 0.7404 ha, accumulated water volume was $10370 \mathrm{~m}^{3}$, water level altitude was 516.14 meters above sea level. The catchment area of the pond Blažňov is $0.598 \mathrm{~km}^{2}$. The dam breach has happened at the night from March 28 to 29, 2006 due to several causes (Fig. 1). The primary cause was the breakdown of the dam stability due to the activity of water rodents that was followed by water seepage through the dam. Another negative factor was an intensive rain that caused fast melting of the snow cover with thickness from 20 to $30 \mathrm{~cm}$. The pond had not been in use for several years and the surface level had not been handled. Water was drained through the gate outlet with diameter of $30 \mathrm{~cm}$. The water flew uncontrolled over the safety weir. The water level height in the safety weir was $23 \mathrm{~cm}$. On the water surface of the pond was the stratified ice layer as thick as $22 \mathrm{~cm}$ that had been formed through the whole winter season. 


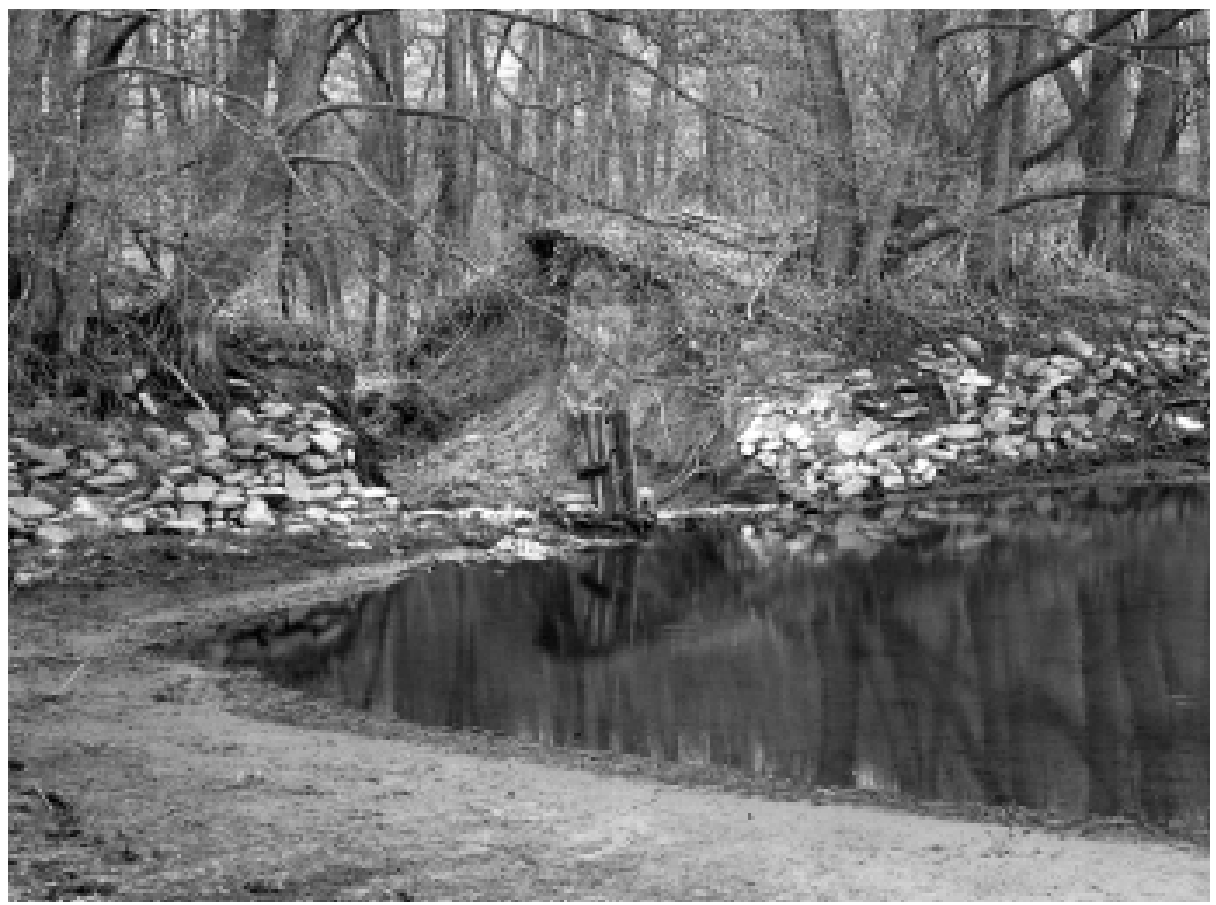

Fig. 1: The Blažňov pond after the dam breach. The depth of the rest of water in the pond was $0.3 \mathrm{~m}$

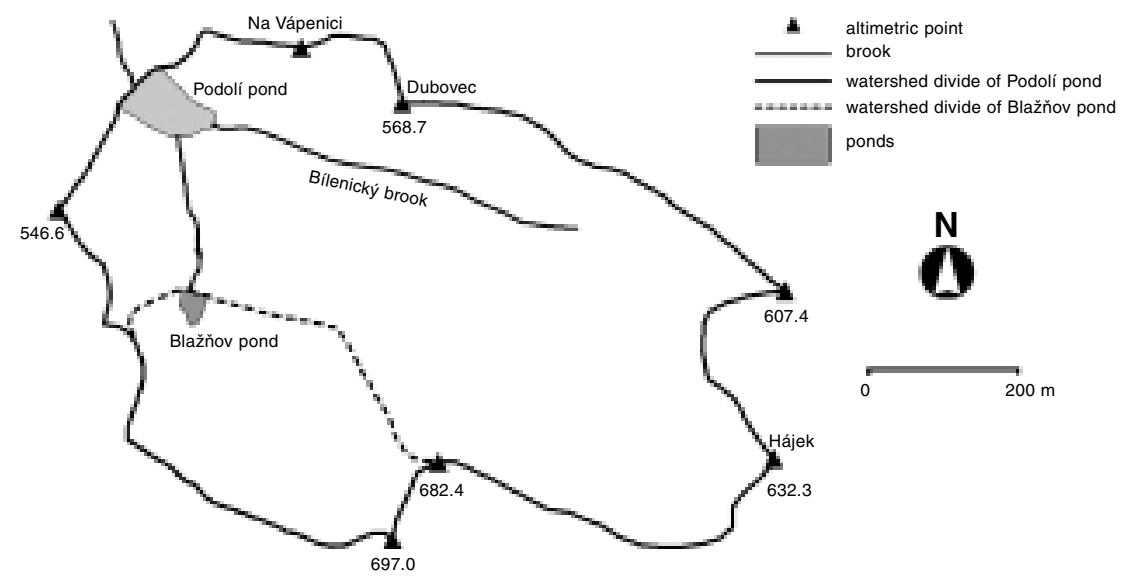

Fig. 2: Schematic map of the study area

The breach was followed by the flood wave that overcame the distance of $570 \mathrm{~m}$ (mean slope gradient $2.8 \%$ ) and flew into the lower situated pond Podolí (497 meters above sea level; see Fig. 2) where it transformed. On March 22, 2006 the 
filling of the Podoli pond started. Area of the pond is 4.3 ha and the accumulated water volume reaches approx. $37000 \mathrm{~m}^{3}$. The total catchment area of the Podoli fish pond is $3.0 \mathrm{~km}^{2}$. Thanks to lucky favourable circumstances the flood wave was accumulated by the empty fish pond Podolí and any consequent catastrophe didn't happen, such as the damage or possible breach of the dam of the pond due to water inflow.

The flood wave that occurred after the dam breach did not cause any serious damages. The first part of the valley of the stream is characteristic by the forest with full-grown trees, the other part continues through the channelized trapezoidal river bed up to the mouth into the pond. Water left the river bed but no damages occurred on the surrounding pastures excepting washed-up wooden pieces. In the upstream part remained spacious sediments of sand gravel originated from the pulped dam, as thick as up to $30 \mathrm{~cm}$ (Fig. 3). The overall cubic content of the material moved by water from the dam was calculated to $253 \mathrm{~m}^{3}$.

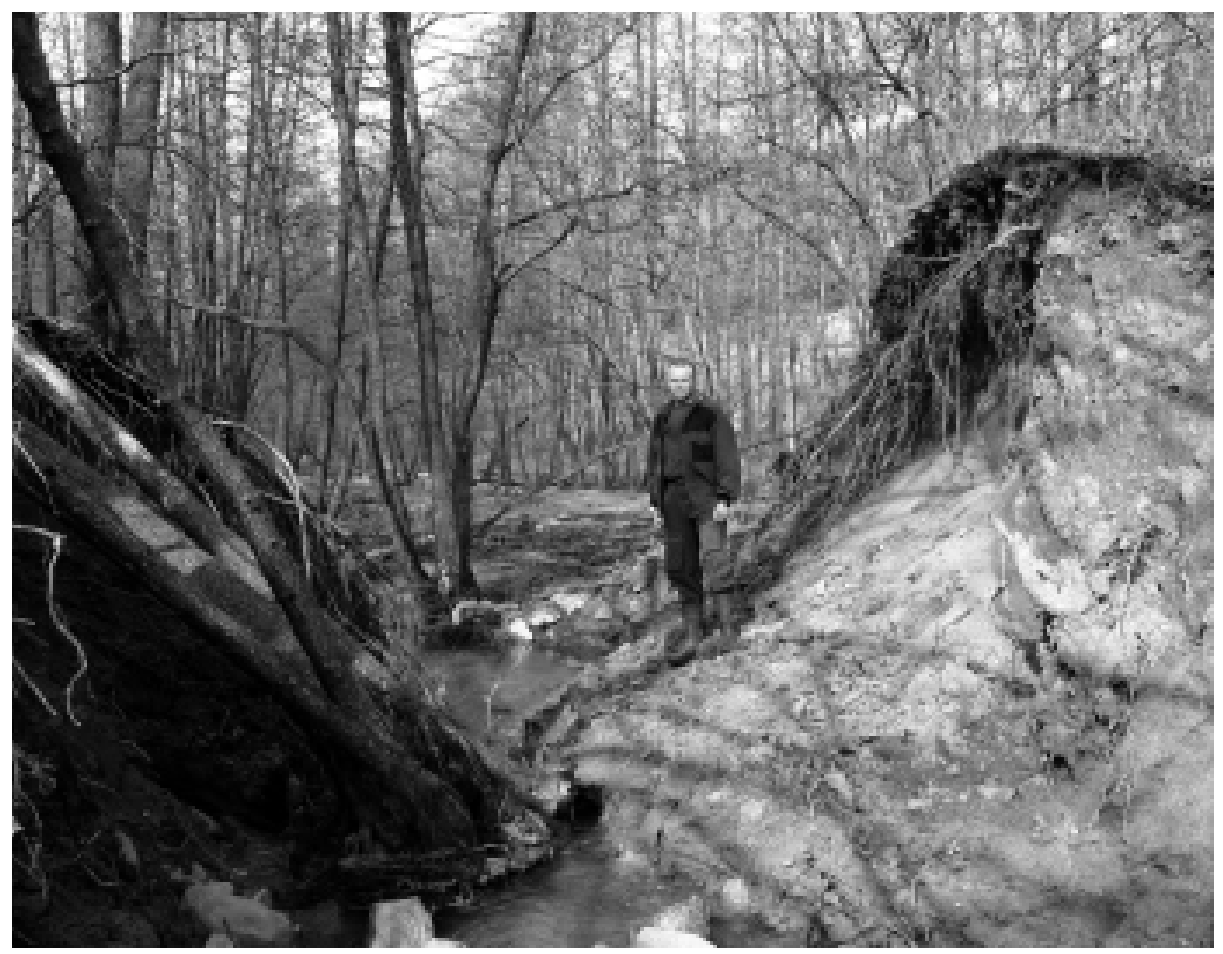

Fig. 3: Detail of the damaged dam of the Blažňov pond

\section{Methodology}

Three days after the pond failure thorough revision of the whole afflicted area was organized and photographic documentation was made. Detailed survey of the flood extent and dam damages has been made. The measurement was made by means of the 
geodetic total station Leica TCR 705 in coordinates JTSK. The coordinates were obtained by free leveling traverse (Čapek, 1992) from the triangulation point U Cihelny (point no. 294, Y $=813213.11 \mathrm{~m}, \mathrm{X}=1129541.58 \mathrm{~m}, \mathrm{Z}=543.83 \mathrm{~m}$ above sea level, orientation to the point no. 280 Podolí).

Using total station and manual measurement with the tape the volume of the material removed from the dam body was measured. Furthermore, the stream trough was plotted as well as its changes due to the flood wave passing through. The scope of the flood wave flooding was plotted in detail. Eight cross sections were measured through the riverbed and the flood plain. The cross sections were selected depending
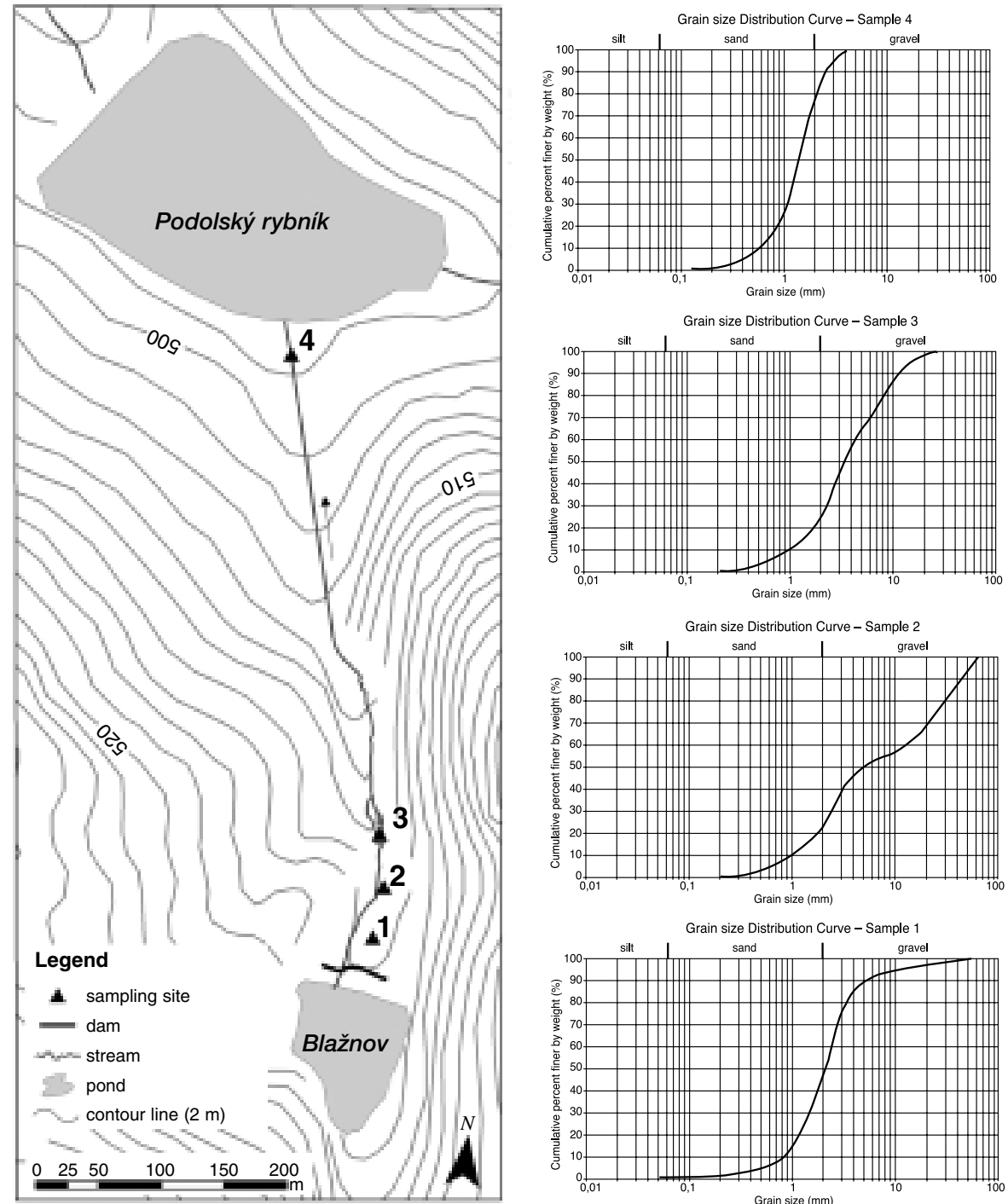

Fig. 4: Localization of recovered samples for grain analysis, grain size distribution curves 
on variable stream gradient and flow cross section. The situation along the bridge was measured in detail where distinctive obstacle for free progress of the flood wave occurred due to packing by the floating wood pieces. Both the ponds were plotted for easy calculation of their capacity. The broken pond was plotted by means of the total station, The Podolí pond was plotted by means of the echo sounder.

Within the catchment area from four places assays of fluvial sediments were removed. Samples were dried up, weighted (electric balance VIBRA, type CG, class III) and analyzed by particle analyses on screening machine FVR C9S using the screen with the mesh sizes $16,4,2,1,0.5,0.25,0.125,0.063,0.05$ and $0.04 \mathrm{~mm}$. In Excel programme grain-size distribution curves were made. The assays were removed within the distances of $30 \mathrm{~m}, 70 \mathrm{~m}, 110 \mathrm{~m}$ and $510 \mathrm{~m}$ from the broken dam of the Blažňov pond (see Fig. 4).

For modelling of the flood extremity and the flood extent the hydrodynamic model HEC-RAS was applied (Hydrologic Engineering Centre - River Analysis System, see Bruner, 2008A, Bruner, 2008B). This model (currently in version 4.0) was developed in Hydrologic Engineering Centre of the U.S. Army Corps of Engineers and belongs to the most applied hydrodynamic models in the Czech Republic and in the world.

Model HEC-RAS needs a large amount of input data for simulations performance. Obtaining these data was the most important and most demanding part of the project solution and it required intensive field survey. First of all, detailed information about morphometry of the riverbed and adjacent floodplain has to be obtained. In model

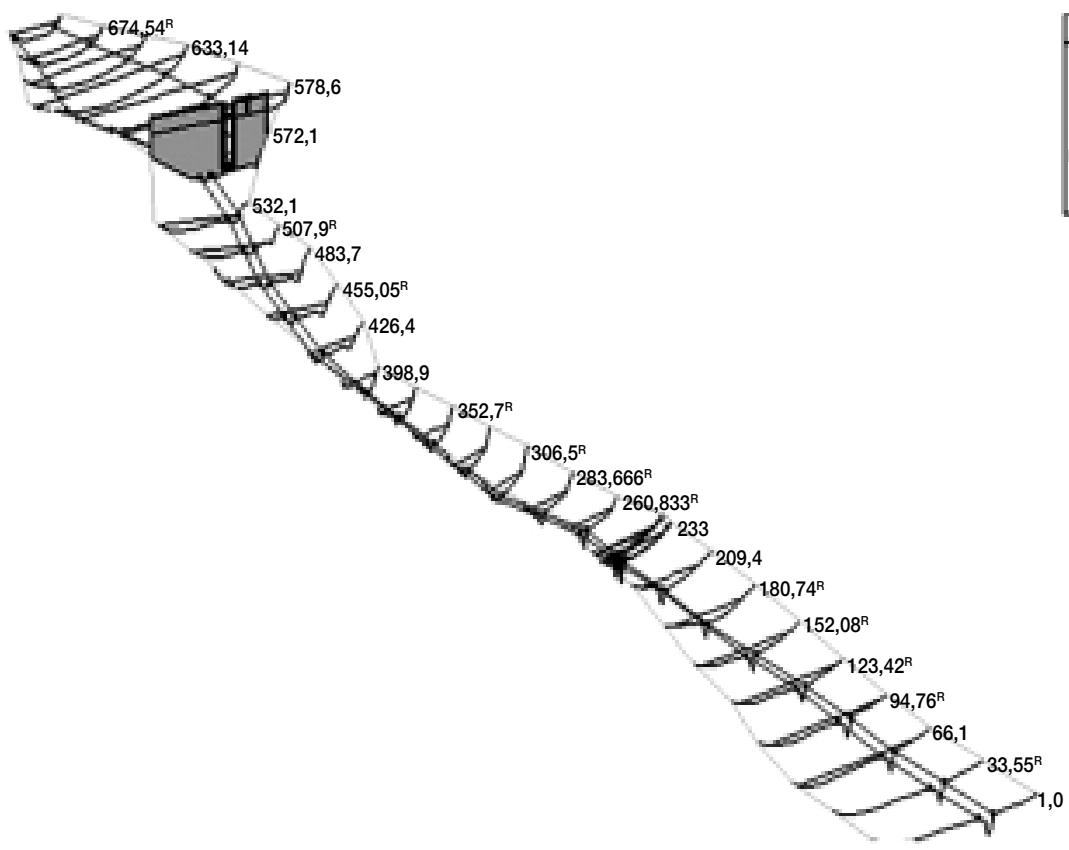

Fig. 5: The 3D scheme of the river network in the HEC-RAS model. Blažňov pond is situated in the upper part of the brook finished with inline structure (represented by grey wall) 
HEC-RAS this is represented by geometry editor which allows a creation of complete river network (river reaches, cross-sections, bridges, culverts inline structures, etc.). Cross-sections were situated perpendicular to the floodplain and riverbed and they were measured with the help of TPS (total geodetic station). In consequent processing an automatic interpolation of cross-sections was necessary to carry out, in order to avoid equation instabilities. Together 29 cross-sections were measured, derived from digital terrain model (DTM) or interpolated. Additional information such as Manning's n values for the riverbed, left and right floodplains were added as the crosssection properties. One culvert has to be simulated in the downstream part of the reach. The dam of the Blažňov pond was represented be inline structure with spillway structure. The 3D schema of the river network is displayed in the Figure 5.

For modelling flood wave extremity a steady flow computation was used. This type of computation uses Bernoulli equation and main results are water stage and simplified velocity distribution in each cross-section. Surely better would be using an unsteady flow (which is corresponding to the real stage) but in the time of the project solution the necessary data were not available. The authors are aware of this marked simplification and thus it is necessary to take the results as the estimation.

For observed reach two simulations were carried out. Due to steady flow computation both of these variants supposed sudden dam breach with no time progress. It means that the dam destruction occurred at once. First step (variant A) was the "calibration" of the model according to flood marks. The aim of this approach was to derive the peak flow of the real flood wave. The aim of the second simulation (variant B) was the computation of the theoretical peak flow in the case of sudden dam breach in the time of maximum water level in the pond before breaching.

\section{Results}

Immediately after this hydrological event the flood extent was measured (based on flood marks). These rather accurate data was necessary for "calibration" of the model. The steady flow simulation based on mentioned data calculated the peak discharge of the flood wave to $7.8 \mathrm{~m}^{3} . \mathrm{s}^{-1}$. The total flooded area between both ponds was 16080 $\mathrm{m}^{2}$. This simulation showed the fact that computed water level in the upper pond in the time of maximum discharge was rather lower than known water level before breaching (514.32 $\mathrm{m}$ a.s.l. instead $516.138 \mathrm{~m}$ a.s.l.). The authors presume, that the above mentioned fact could indicate progressive destruction of the dam.

Based on these facts the second theoretical simulation was carried out. This simulation supposed the same water level in the pond as it was before destruction of the dam. In this case a peak flow reached $56.6 \mathrm{~m}^{3} . \mathrm{s}^{-1}$ and the area of $26870 \mathrm{~m}^{2}$ was flooded. The main results are concluded in the table 1 . The flooded area for both simulations is displayed in the Figure 6.

The velocity distribution through the reach is presented in the Figure 7. The lines represent the velocities in all nodes of the river network (cross-sections) for the channel, the right and the left bank. Rapid decrease at channel distance $572 \mathrm{~m}$ indicates a presence of the pond, in this time almost empty. 


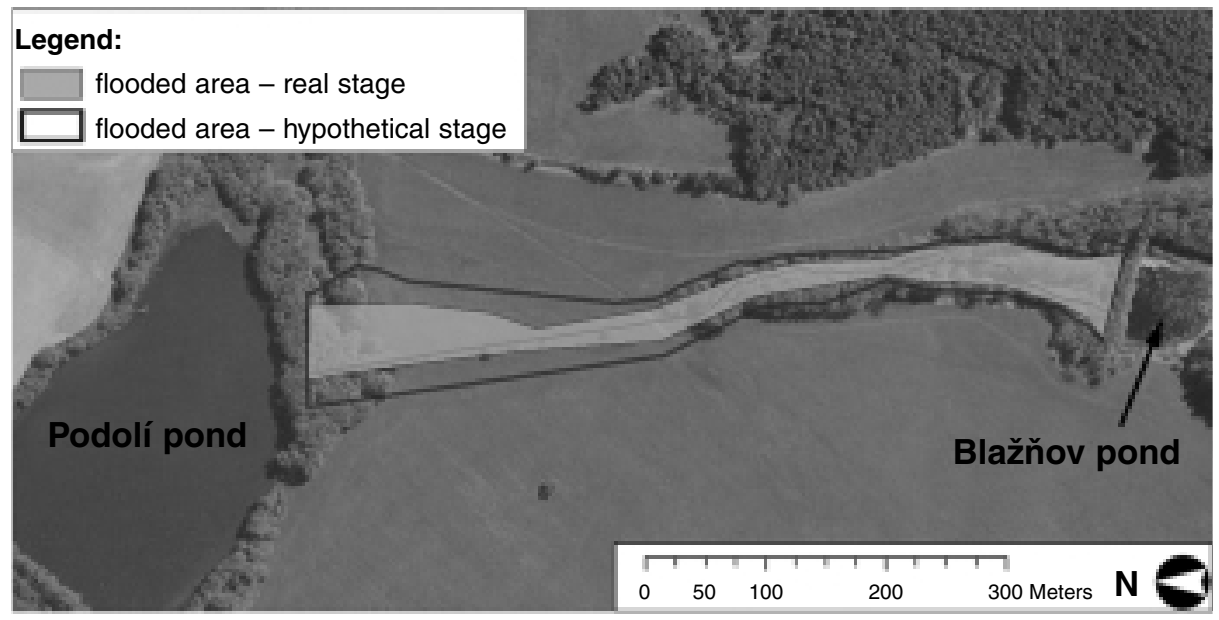

Fig. 6: Flooded area for both simulated variants - real stage (calibrated by means of measured data) and hypothetical stage (suppose sudden breaching with time of destruction close to zero and with maximal water level)

Table 1: Main results for both simulated variants

\begin{tabular}{|c|c|c|c|c|}
\hline & Peak flow $\left[\mathrm{m}^{3} . \mathrm{s}^{-1}\right]$ & Average velocity $\left[\mathrm{m} . \mathrm{s}^{-1}\right]$ & Flooded area $\left[\mathrm{m}^{2}\right]$ & Time of progress [min] \\
\hline Variant A & 7.8 & 1.25 & 16080 & 9.27 \\
\hline Variant B & 56.6 & 1.70 & 26870 & 6.80 \\
\hline
\end{tabular}

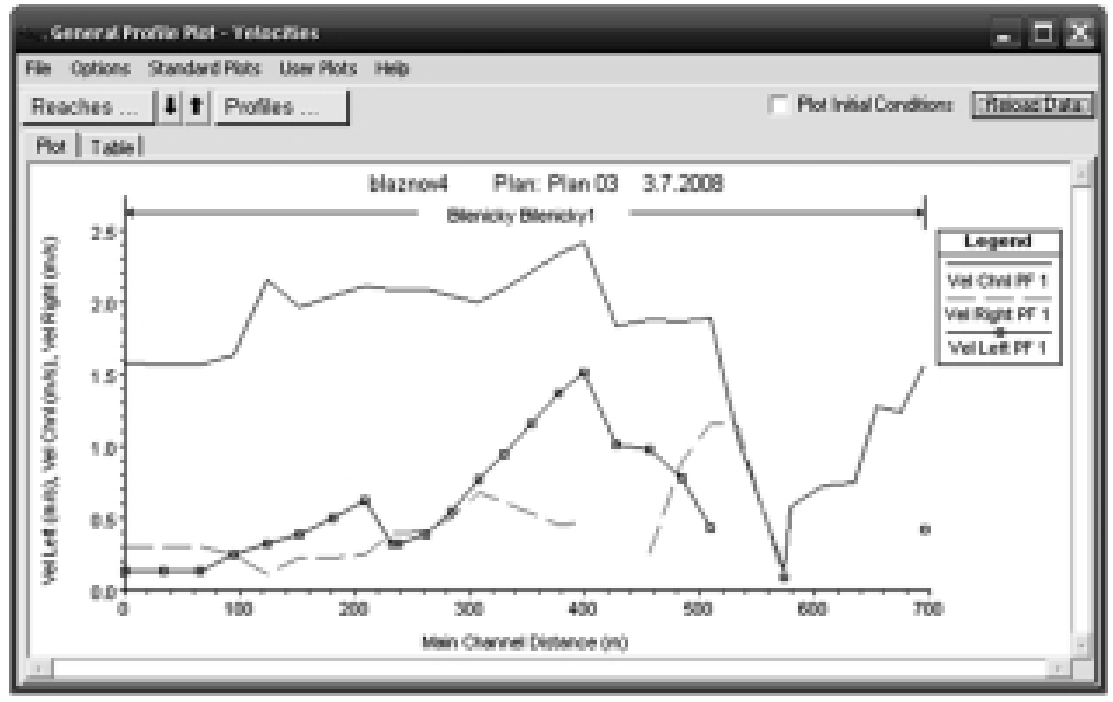

Fig. 7: Change of velocity throughout the whole reach. The line without markers represents channel velocity, line with square marker represents velocities in the inundation bank and dashed line represents velocities in the right inundation 
The flow velocity as well as the grain size of transported and deposited materials depends on the flood phase and on the river reach. Gravel is transported simultaneously with the sand. When the flow velocity decreases, the gravel sediments and the sand is transported until additional velocity decreasing (Růžičková et al., 2003). This was proved also by obtained sediment samples, where the probe no. 4 (obtained within the largest distance from the broken dam) displays three times higher abundance of sand fraction compared to probes nos. 1, 2 and 3 (see Fig. 8).

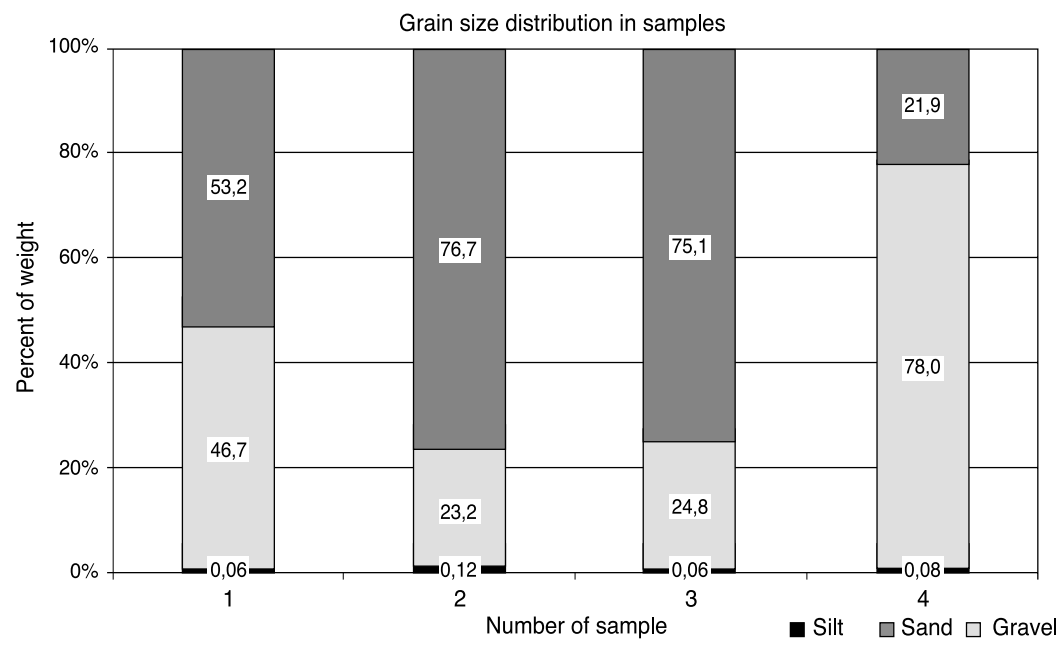

Fig. 8: Grain size distribution in samples

In all probes the ratio of gravel and sand fractions coincidently outweighs over the fine-grain material of the grain size under $0.05 \mathrm{~mm}$ (Tab. 2). The probes no. 1 and no. 3 are the most similar regarding the grain compositions. The coarsest sample is the probe no. 2 (fine gravel, grain size approx. $5 \mathrm{~mm}$ ). Grain size distribution of samples 1 and 3 corresponds to sand and gravel and sample 4 contains particles from 1 to $2 \mathrm{~mm}$ (sand).

Table 2: Percentage share of grain size in recovered samples

\begin{tabular}{|c|c|c|c|c|c|c|}
\hline \multirow{2}{*}{ Particle size ( $\mathrm{mm}$ ) } & \multicolumn{4}{|c|}{ Percent of weight } & \multirow{2}{*}{\multicolumn{2}{|c|}{ Sediment }} \\
\hline & Sample 1 & Sample 2 & Sample 3 & Sample 4 & & \\
\hline finer than 0.05 & 0.05 & 0.07 & 0.04 & 0.05 & \multirow{2}{*}{\multicolumn{2}{|c|}{ Silt }} \\
\hline $0.05-0.063$ & 0.02 & 0.05 & 0.02 & 0.03 & & \\
\hline $0.063-0.125$ & 0.19 & 0.13 & 0.19 & 0.27 & \multirow{2}{*}{ Fine } & \multirow{5}{*}{ Sand } \\
\hline $0.125-0.25$ & 0.98 & 0.48 & 0.90 & 1.43 & & \\
\hline $0.25-0.5$ & 3.26 & 2.73 & 2.77 & 6.25 & \multirow{2}{*}{ Medium } & \\
\hline $0.5-1$ & 9.39 & 7.12 & 6.55 & 19.27 & & \\
\hline $1-2$ & 32.88 & 12.76 & 14.39 & 50.76 & Coarse & \\
\hline $2-4$ & 39.26 & 23.87 & 32.77 & 21.78 & \multirow{2}{*}{ Fine } & \multirow{3}{*}{ Grave } \\
\hline $4-16$ & 9.66 & 16.54 & 38.28 & 0.16 & & \\
\hline coarser than 16 & 4.30 & 36.26 & 4.08 & 0.00 & Medium & \\
\hline
\end{tabular}




\section{Discussion}

By measurement, analysis of data and modelling it is necessary to take into account many uncertainties which appear during particular steps of the project solution.

First the general modelling approach is important. The flood wave progress and transformation could be simulated based on equation for steady or unsteady flow. The result of the first mentioned type could be for example information about water stages in each cross-section and together with DTM also flooded area. The velocities can be also computed. For unsteady flow a derivation of flood hydrograph is typical, it means that time component is also added. However unsteady flow simulations need more data (denser cross-sections, more hydrodynamic coefficients for bridges, culverts or weirs) and also boundary and initial conditions are demanding on data. The lack of data could lead to equation instability and simulation collapse. Although some unsteady simulation was made, there were no acceptable results (instability in computation). In accordance to these facts only steady flow simulations have run. Then it is necessary to regard computed results as estimation and with help of them only to document possibilities of working with measured data.

The grain-size distribution curves analysis documents reduction of the carrying capacity down the stream from the Blažňov pond dam which was documented by increasing ratio of fine-grain components in removed samples. The flow velocity within the whole length of the water stream was so high that no fine-grain sediments (silt and clay) settled down. It is assumed that sedimentation of particles took place in the Podolí pond.

\section{Conclusion}

The main goal of this study was a reconstruction of the flood wave in small brook which was caused by breaching of the Blažňov pond dam. For computation of the peak flow, velocities and flooded area the hydrodynamic model HEC-RAS was used (1D model). The peak flow of the flood wave reached up to $7.8 \mathrm{~m}^{3} . \mathrm{s}^{-1}$, and the area of $16080 \mathrm{~m}^{2}$ was flooded. This simulation indirectly showed that breaching probably didn't occur suddenly and thus the peak discharge reached relatively low value. The theoretical simulation of sudden dam destruction by maximum water level in the pond calculated the peak flow $56.6 \mathrm{~m}^{3} . \mathrm{s}^{-1}$ and larger flooded area $26870 \mathrm{~m}^{2}$. Due to many simplifications computed results have to be taken as estimative. The analysis of grainsize distribution curves of 4 taken samples confirmed reduction of the carrying capacity down the stream from the Blažňov pond. The flow velocity within the whole length of the water stream was very high and no silt and clay settled down. Their sedimentation has happened in the Podolí pond.

\section{Acknowledgements}

The presented research was funded by research plan MSM 0021620831 "Geographical Systems and Risk Processes in the Context of Global Changes and 
European Integration" in cooperation with project VaV SM/2/57/05 "Long-term changes in fluvial ecosystems in floodplains affected by extreme floods".

\section{References}

BRUNER, G.W. ET AL. (2008A): HEC-RAS, River Analysis System Reference Manual. Davis, U.S. Army Corps of Engineers.

BRUNER, G.W. ET AL. (2008b): HEC-RAS, River Analysis System User's Manual. Davis, U.S. Army Corps of Engineers.

ČAPEK, R. ET AL. (1992): Geografická kartografie. Praha, SPN.

RŮŽIČKOVÁ, E. ET AL. (2003): Kvartérní klastické sedimenty České republiky. Struktury a textury hlavních genetických typů. 1. vydání, Praha, Česká geologická služba.

\section{Résumé}

\section{Protržení hráze rybníka Blažňov způsobené extrémní hydrologickou situací}

Příspěvek se zabývá modelováním průběhu povodňové vlny, která vznikla v důsledku protržení hráze rybníka Blažňov. K protržení došlo v noci z 28. 3. na 29. 3. 2006 v důsledku zvýšeného přítoku vody, který byl způsoben intenzivními deštovými srážkami a táním sněhové pokrývky. Hráz rybníka je sypaná písková, v době protržení již byla narušena činností vodních hlodavců. Povodňová vlna postupovala údolím potoka v délce zhruba $0,7 \mathrm{~km}$ a následně vyplnila níže ležící rybník Podolí, který byl toho času vypuštěný. Povodňová vlna se v něm transformovala. Terénní mapování dráhy průtrže a vyměřování prríčných profilů údolím potoka bylo provedeno geodeticky, pomocí totální stanice. Na čtyřech místech dráhy protržení byl proveden odběr naplavených sedimentů a byla sledována jejich zrnitost. Pro průchod povodňové vlny ve sledovaném úseku byl použit hydrodynamický 1D model HEC-RAS. Pomocí modelování byl vypočten maximální průtok povodňové vlny $7,8 \mathrm{~m}^{3} \cdot \mathrm{s}^{-1}$, což odpovídá zaplavené ploše $16080 \mathrm{~m}^{2}$. Na základě výsledků modelu se autoři domnívají, že došlo $\mathrm{k}$ postupné destrukci hráze a hodnota maximálního průtoku byla tedy poměrně nízká. Následná teoretická simulace ukázala, že při náhlém protržení za maximální hladiny v rybníce by maximální průtok činil $56,6 \mathrm{~m}^{3} . \mathrm{s}^{-1}$ a byla by zatopena oblast o ploše $26870 \mathrm{~m}^{2}$. Výsledky je potřeba díky četným zjednodušením vnímat jako orientační. Analýza zrnitostních křivek dokumentuje snížení unášecí schopnosti vodního toku směrem od hráze rybníka Blažňov, což je doloženo zvýšením podílu jemnozrnných komponent $\mathrm{v}$ odebraných vzorcích. Rychlost proudění $\mathrm{v}$ celém průběhu vodního toku byla natolik velká, že nedocházelo k ukládání jemnozrnných sedimentů - prachu a jílu. Lze předpokládat, že k jejich sedimentaci došlo až ve vodním prostředí Podolského rybníka.

Charles University in Prague, Faculty of Science, Department of Physical Geography and Geoecology,

Albertov 6

12843 Prague 2

Czech Republic

e-mail: sobr@natur.cuni.cz,jenicek@natur.cuni.cz, vocadlov@natur.cuni.cz phone: +420221995525 